\title{
The incidence of some components of the metabolic syndrome in children in medium sized town and rural area in Poland
}

\section{ABSTRACT}

Introduction. The aim of this study was to compare the prevalence of chosen components of the metabolic syndrome in Caucasian children and adolescents living in small town and rural area in central Poland. The parents' knowledge on eating habits and level of physical activity of their children was also analyzed. Material and methods. We measured anthropometric parameters, fasting blood glucose, systolic and diastolic blood pressures in 842 school children aged 7 to 16 years. Questionnaire was used to assess the parents' knowledge about the eating habits and physical activity of the children.

Results. In studied populations the prevalence of obesity was higher in boys than in girls. Blood pressure $\geq$ c95 was observed significantly more often in obese individuals. There was a positive correlation between obesity and abdominal obesity. Increased waist circumference was observed more frequently in boys in the youngest age group. Elevated blood pressure was most frequently seen in children with abdominal obesity. Adolescents aged 16 years spent the most time in front of the TV/computer, and those most often consumed "fast foods" meals. Both in small town and rural areas girls were less physically active than boys. Over $50 \%$ of parents in both populations regarded the physical

Address for correspondence: dr n. med. Jacek Kasznicki

Klinika Chorób Wewnętrznych, Diabetologii

i Farmakologii Klinicznej, Uniwersytet Medyczny w Łodzi

Phone: (+48 42) 2014385

Fax: (+48 42) 2014380

e-mail: jacek.kasznicki@umed.lodz.pl

Clinical Diabetology 2017, 6, 6, 195-203

DOI: 10.5603/DK.2017.0032

Received: 14.11.2017

Accepted: 06.12.2017 activity of children as normal, and almost $90 \%$ of the parents accepted children's dietary habits.

Conclusions. Our results point out the key role of environmental factors and gender in the development of overweight and obesity. It seems necessary to take all preventive measures to reduce the risk of complications of obesity in the future life. (Clin Diabetol 2017; 6, 6: 195-203)

Key words: metabolic syndrome, children, adolescents, rural part of Poland

\section{Introduction}

In the last decades, the dynamic increase in the prevalence of overweight and obesity is seen all over the world [1]. Research shows that overweight and obesity are found in every two adult polish citizen [2]. The prevalence of obesity has also dramatically increased among children and adolescents. According to the International Obesity Task Force (IOTF) about $10 \%$ of children between 5 and 17 years of age have increased body weight, while $2-3 \%$ can be classified as obese $[3,4]$. The prevalence of overweight and obesity as well as elevated blood pressure in the population of Polish children and adolescents aged 7-18 years may reach about $20 \%$ in some areas $[5,6]$. Prevalence of overweight and obesity in the youngest age groups influence to a large extent the quality of life and survival in later stages of life [7]. The study by Reilly et al. demonstrated that $26 \%$ of obese children aged 1 to 3 years and up to $83 \%$ aged 10 to 15 years will be obese in the adulthood [8]. Obesity increases the risk of T2DM, hypertension, atherosclerosis, cancer, bone diseases and psychiatric disorders, and depression [9]. 
Table 1. Proposed criteria of metabolic syndrome in children

\begin{tabular}{lll}
\hline Criterion & Adults, ATP III children & ATP III modified by Cruz et al. \\
\hline High TG level & $\geq 1.7 \mathrm{mmol} / \mathrm{l}(\geq 150 \mathrm{mg} / \mathrm{dl})$ & $\geq 90$ th percentile (age- and sex-specific) \\
Low HDL-C level & Men $\leq 1.1 \mathrm{mmol} / \mathrm{l}(\leq 40 \mathrm{mg} / \mathrm{dl})$ & $\leq 10$ th percentile (age- and sex-specific) \\
& Women $\% 1.3 \mathrm{mmol} / \mathrm{l}(\% 50 \mathrm{mg} / \mathrm{dl})$ & $\geq 90$ th percentile (age-, sex- and race-specific) \\
Abdominal obesity (via WC) & Men $>102 \mathrm{~cm}$ & \\
& Women $>88 \mathrm{~cm}$ & $\geq 5.6 \mathrm{mmol} / \mathrm{l}(\geq 100 \mathrm{mg} / \mathrm{dl})$ \\
High FPG level & $\geq 5.6 \mathrm{mmol} / \mathrm{l}(\geq 100 \mathrm{mg} / \mathrm{dl})$ & $\geq 90$ th percentile (age-, sex- and height-specific) \\
Hypertension & SBP $\geq 130 \mathrm{~mm} \mathrm{Hg}, \mathrm{DBP} \geq 85 \mathrm{~mm}$ Hg or using & \\
\hline
\end{tabular}

Obesity, especially abdominal one, hypertension (HT) and disorders of carbohydrate and lipid metabolism, basic features of the metabolic syndrome (MS) (criteria are shown in table 1) are increasingly often diagnosed in children and adolescents. This creates serious, medical, social, as well as economic problems $[10,11]$. For this reason it is extremely important to search for modifiable causes, since it may help to take effective preventive measures in the future.

The aim of this study was to evaluate the prevalence of overweight, obesity, low body weight, elevated blood pressure, abnormal fasting blood glucose levels and eating habits in the population of children and adolescents in medium sized town — Zgierz (ZG) and rural area - Leczyca (LE) in Lodz region (central Poland). The knowledge of parents on eating habits and degree of physical activity of their children was also analyzed.

\section{Material and methods}

842 Caucasian children and adolescents representative of a regional population, aged 7 to 16 years, were recruited into study - 504 school children in a middle sized city of ZG (318 girls, 186 boys) and 338 school children in rural area of LE (166 girls, 172 boys). More than $50 \%$ (respectively $56 \%$ in ZG and $62 \%$ in LE) of children and adolescents included into the study belonged to the youngest age group (7-12 years). Additionally, 1137 parents/legal guardians of included children participated in the study, among them 728 in ZG and 409 LE.

A complete physical examination was conducted, and subsequently, height, body mass, waist circumference, hip circumference, fasting blood glucose were measured in all children participating in the study. Weight was measured in children wearing light clothes and no shoes while standing. Height was measured with a stadiometer, in children standing in an upright position without shoes, heels together, and the head positioned parallel to the floor. Waist circumference (WC) was measured at the midpoint between the lower costal border and the iliac crest at the end of a normal expiration. Height and WC were measured to the nearest $0.1 \mathrm{~cm}$, and weight was measured to the nearest $0.1 \mathrm{~kg}$. The percentiles were assessed using tables for children and adolescents of Lodz region (Poland) [12]. Additionally body mass index (BMI) and waist-hip ratio (WHR) were calculated.

Systolic and diastolic blood pressures (SBP and DBP respectively) were taken twice on the left arm at the end of examination, after the participant was sitting comfortably for $5 \mathrm{~min}$ with the use of the cuff of mercury sphygmomanometer with appropriately sized. The average of two measurement was used for the analysis. Hypertension (elevated SBP or DBP) was defined as a value that exceeded the 90th percentile for sex, age, and height or the use of anti-hypertensive medication [13].

The classification of blood pressure in children and adolescents was based on the Fourth Report on the Diagnosis, Evaluation and Treatment of High Blood Pressure in Children and Adolescents (IVR) [13] and the assessment of nutritional status on the basis of BMI according to the criteria proposed by the WHO [14].

Questionnaire prepared for the study purpose was used to assess the parents' knowledge about the principles of nutrition and physical activity of children.

The protocol for this study was reviewed and accepted by the Ethics Committee of the Medical University of Lodz (Poland). The patients' parents signed a written consent form when they and their children/ /adolescent agreed to be enrolled.

\section{Statistical analysis}

Data were summarized using frequency tables, summary statistics, confidence intervals, and $p$ values, as appropriate. Demographic data are expressed as means \pm SD for continuous variables and frequencies and percentages for categorical variables. Parametric model assumptions were assessed using Shapiro-Wilk test to verify normality. Chi-square test was used to 
Table 2. Anthropometric parameters of study participants, ZG vs. LE

\begin{tabular}{|c|c|c|c|c|c|c|c|c|c|c|c|c|c|c|}
\hline & \multicolumn{2}{|c|}{ Mean } & \multicolumn{2}{|c|}{ Median } & \multicolumn{2}{|c|}{ Min } & \multicolumn{2}{|c|}{ Max } & \multicolumn{2}{|c|}{ Q25 } & \multicolumn{2}{|c|}{ Q75 } & \multicolumn{2}{|c|}{ SD } \\
\hline & LE & ZG & LE & ZG & LE & ZG & LE & ZG & LE & ZG & LE & ZG & LE & ZG \\
\hline Age (years) & 12.3 & 12.5 & 12 & 12 & 8 & 7 & 16 & 16 & 10 & 11 & 16.0 & 15.0 & 2.6 & 2.5 \\
\hline Height $[\mathrm{cm}]$ & 152.3 & 154.7 & 152 & 157 & 119 & 118 & 189.5 & 188 & 142 & 143 & 163.0 & 165.0 & 14.2 & 15.2 \\
\hline Body mass $[\mathrm{kg}]$ & 47.3 & 49.5 & 46 & 49 & 23 & 19.8 & 134.6 & 102 & 35 & 37.9 & 56.0 & 59.0 & 16.5 & 15.9 \\
\hline BMI $\left[\mathrm{kg} / \mathrm{m}^{2}\right]$ & 20 & 20.1 & 19.4 & 19.6 & 12.8 & 12 & 45.2 & 36 & 16.9 & 17 & 21.9 & 22.4 & 4.3 & 3.9 \\
\hline Glycemia [mg/dl] & 102.4 & 88.3 & 102 & 89 & 78 & 51 & 144 & 139 & 96 & 80 & 109.0 & 96.0 & 9.9 & 13.9 \\
\hline $\mathrm{SBP}[\mathrm{mm} \mathrm{Hg}]$ & 109.4 & 114.9 & 110 & 115 & 80 & 85 & 160 & 160 & 100 & 105 & 120.0 & 124.0 & 14.4 & 13.2 \\
\hline $\mathrm{DBP}[\mathrm{mm} \mathrm{Hg}]$ & 64.5 & 69.2 & 60 & 70 & 48 & 45 & 92 & 100 & 60 & 60 & 70.0 & 75.0 & 7.5 & 8.8 \\
\hline Waist circumference $[\mathrm{cm}]$ & & 72.4 & & 71 & & 48 & & 112 & & 65 & & 79.0 & & 10.5 \\
\hline Hip circumference $[\mathrm{cm}]$ & & 87.8 & & 88 & & 61 & & 121 & & 81 & & 95.0 & & 10.9 \\
\hline WHR $[\mathrm{cm}]$ & & 0.8 & & 0.8 & & 0.7 & & 1.0 & & 0.8 & & 0.9 & & 0.1 \\
\hline
\end{tabular}

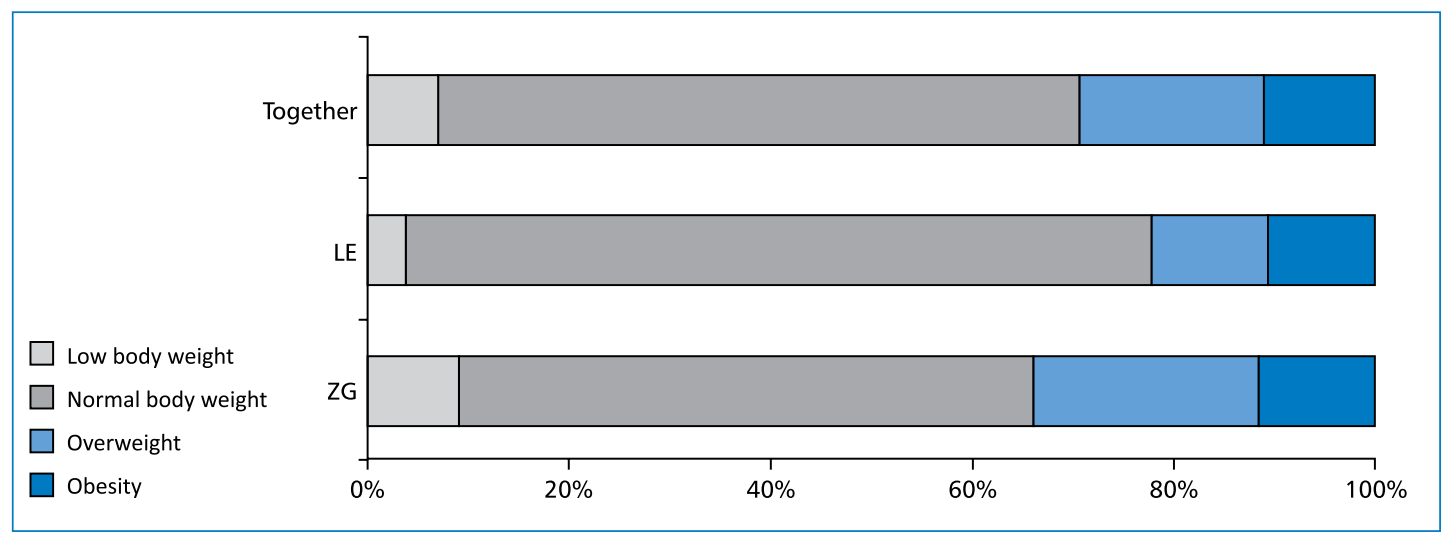

Figure 1. Body weight of study participants, LE vs. ZG

compare categorical variables. The distribution of quantitative variables was assessed using the Shapiro-Wilk test of normality. Since in most cases the distribution characteristics differed from the normal, Mann-Whitney $U$ test was used to compare between the groups. Categorical variables between the groups were contrasted using the Chi-square $\left(\chi^{2}\right)$ test. Significance was set at $p<0.05$. The statistical analysis was performed using the Statistica software (version 10).

\section{Results}

All 842 children and adolescents were included into the final analysis. Anthropometric parameters of the examined children are shown in Table 2.

Abnormal body weight (overweight, obesity, low body weight) was observed more frequently in ZG compared to LE. Low body weight was seen in $9.1 \%$ of ZG and $3.9 \%$ of LE populations $(p=0,003)$. Overweight was found in $22.4 \%$ and $11.5 \%$ of $Z$ G and LE populations respectively $(p=0.006)$. Obesity was seen in $11.5 \%$ children in ZG and $10.7 \%$ of children in
LE and the difference was not statistically significant ( $p>0.05$ ) (Fig. 1).

\section{Gender differences in body weight}

In the study population, a greater percentage of obese children was seen in boys both in LE (15.7\%) and ZG (14.5\%) compared to girls (ZG 9.8\%; LE 5.4\%) $(p=0,002)$. Additionally the percentage of overweight boys was higher in ZG (22.6\%) compared to LE (8.7\%) $(p=0.002)$

Girls in ZG compared with girls in LE demonstrated a greater percentage of low weight (9.4 and 3.0\% respectively), overweight ( 22.3 and $14.5 \%$ respectively) and obesity (9.8 and $5.4 \%$ respectively). However significant difference was noted only for low body weight $(p=0.02)$ and overweight $(p=0.04)$.

\section{Age differences in body weight}

A percentage of obesity in youngest age group (7-12 years old) was similar in LE (12.4\%) and ZG (11.7\%). Overweight and low body weight was seen in 


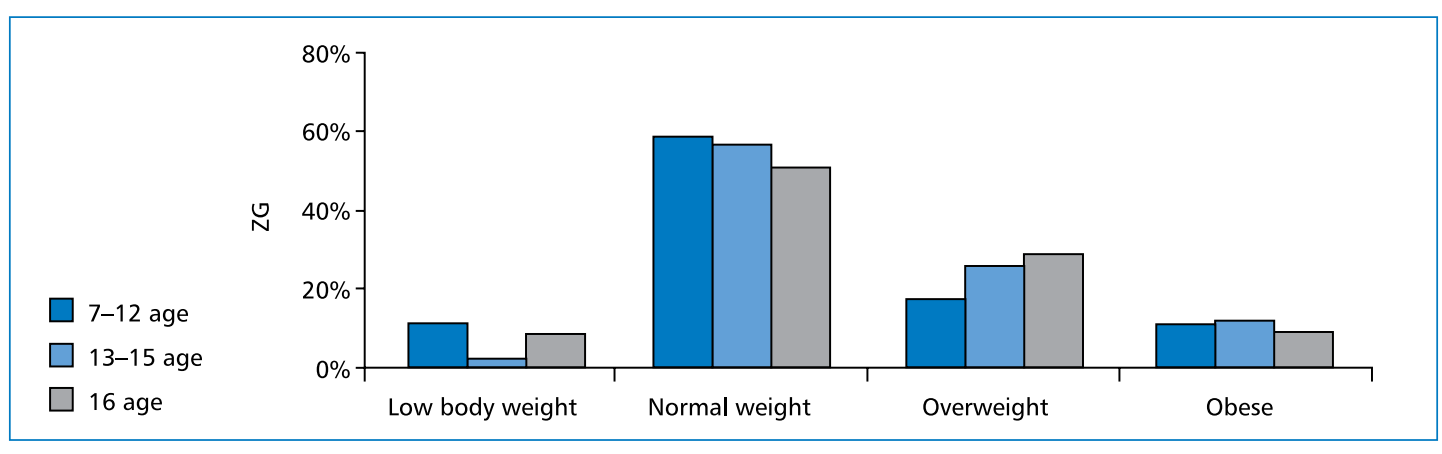

Figure 2. Comparison of body weight of study participants in ZG

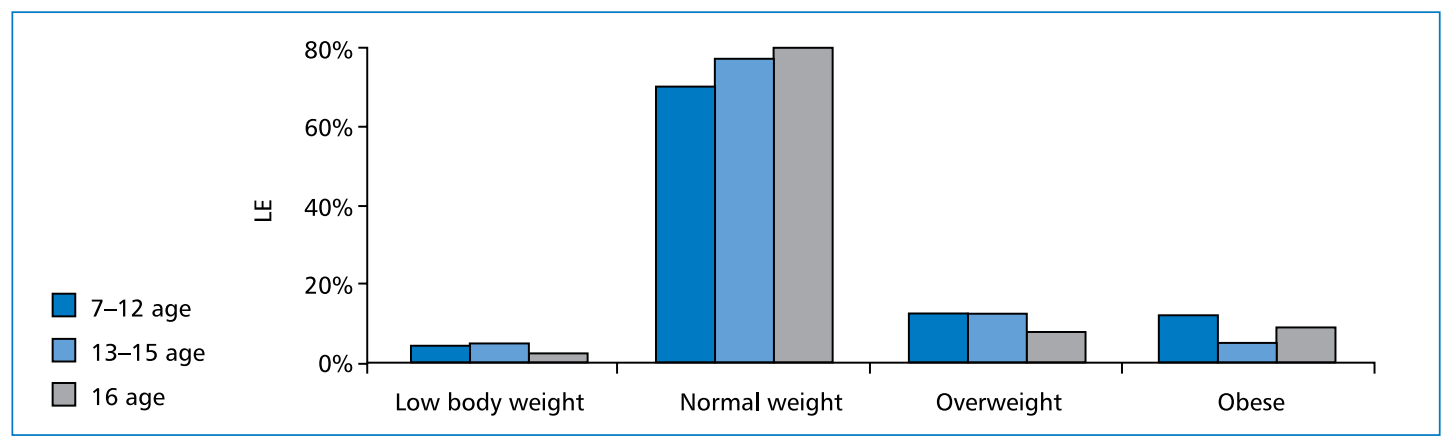

Figure 3. Comparison of body weight of study participants in LE

a greater percentage of participants in 7-12 year-olds in ZG $(17.8 \%, 11.4 \%$ respectively), compared with LE (12.8\%, 4.3\% respectively) (Fig. 2 and Fig. 3). In this age group statistically significant difference between LE and ZG was seen only in the incidence of the low body $(p=0.005)$.

In the group of 13-15 year olds higher percentage of overweight and obese children was demonstrated in ZG ( 26.7 and $12.9 \%$ respectively) as compared with LE (12.5 and 5.0\% respectively). In contrast, a higher percentage of adolescents with low body weight was shown in 13-15 year olds in the LE (5.0\%) compared to ZG (3.0\%) ( $p>0.05)$ (Fig. 2) and (Fig. 3).

In 16 year-olds the percentage of obesity was similar in LE and ZG (respectively 9.1\%, 9.8\%). A larger proportion of overweight adolescents as well as individuals with low body weight was observed in ZG (29.5 and 9.0\% respectively) as compared with LE (8.0 and $2.3 \%$ respectively). Significant difference was shown only for the prevalence of overweight ( $p=0.001$ ) (Fig. 2 and Fig. 3).

WC $\geq 90$ c was noted in $14.5 \%$ of the study population, significantly more often $(p<0.004)$ in boys $(20.4 \%)$ than in girls (11.0\%) (Fig. 4). There was a statistically significant relationship of weak force ( $C=0.181$ ) between the presence of abdominal obesity and gender.
The highest percentage of children with WC $\geq 90 \mathrm{c}$ was found in the youngest age group (7-12 year-olds), and the smallest in the group of 16 year-olds (18.2\%, $9.8 \%$ respectively). The difference reached statistical significance difference between the incidence of obesity in these groups $(p<0.04)$. It has been shown that there is a correlation of weak force $(C=0.164)$ between the occurrence of obesity and age of patients. The results showed that $79.3 \%$ of children and adolescents with WC $\geq 90$ c were obese. WC $\geq 90$ c was seen in $18.6 \%$ overweight and only $2.1 \%$ normal weight subjects (Fig. 5). Significant difference was seen between the incidence of WC $\geq c 90$ in obese compared to normal weight children $(p=0.001)$. There is a strong correlation ( $C=0.646$ ) between the presence of abdominal obesity and body mass.

In the study population higher blood pressure was demonstrated in ZG group compared to LE (19.2 and $13.3 \%$ respectively) and this difference was statistically significant (Fig. 6) $(p=0.003)$.

The greater percentage of boys in ZG demonstrated high blood pressure than in the LE (29\%; 14\%) $(p=0.001)$. There were no statistical differences in this respect in girls. Both in ZG and LE high blood pressure $(\geq 95 c)$ was seen in the greater proportion of obese children and adolescents ( 41.4 and $27,8 \%$ respectively) 


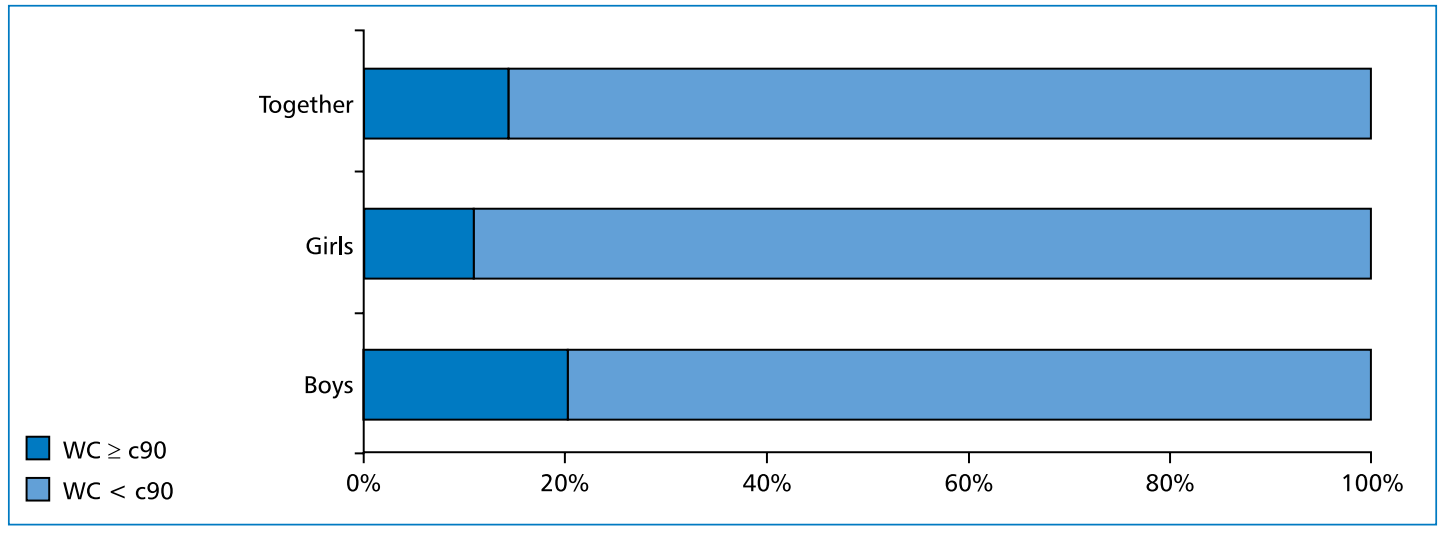

Figure 4. The frequency of increased WC ( $\geq 90 c)$ according to gender

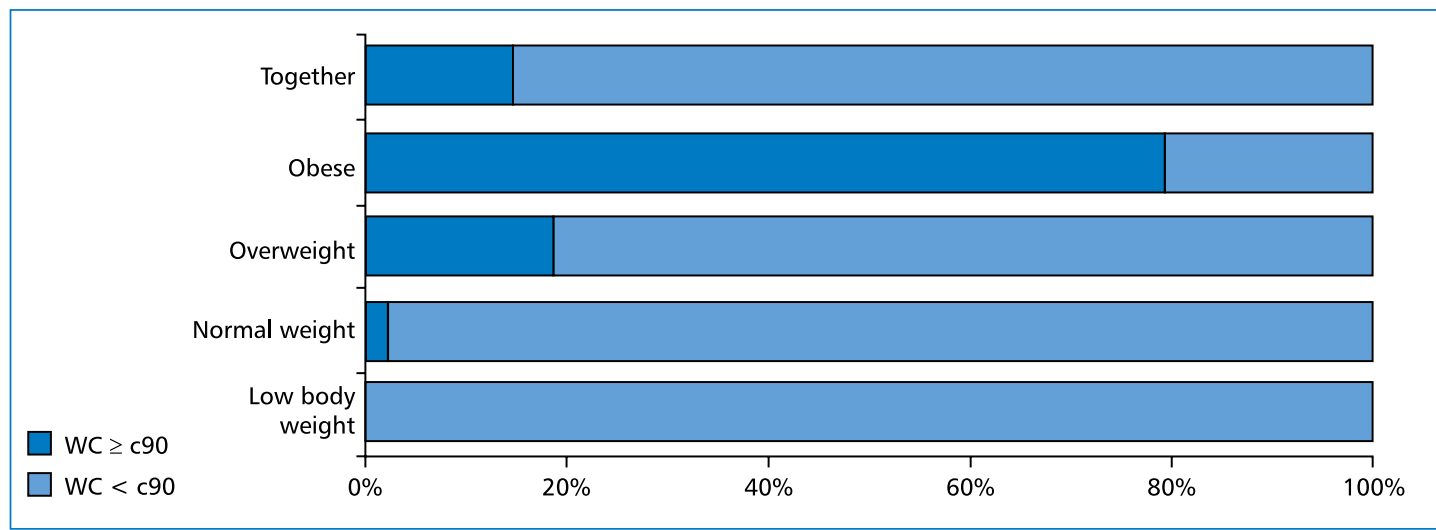

Figure 5. The $W C \geq 90 \mathrm{c}$ in different weight groups

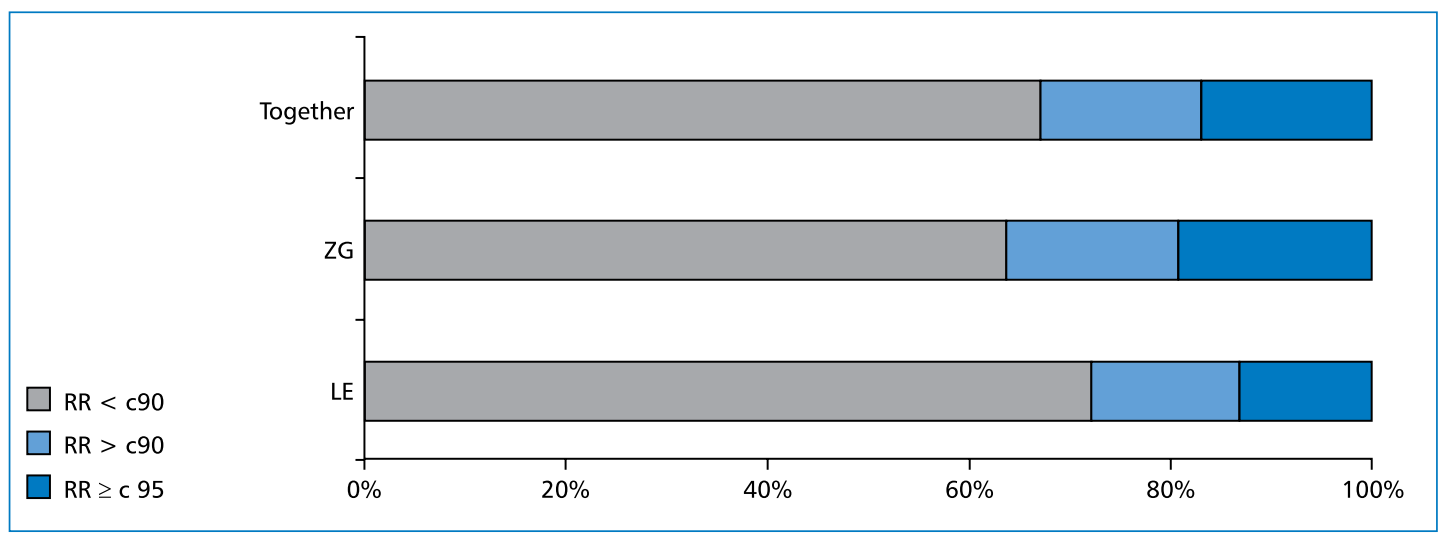

Figure 6. Comparison of blood pressure of study participants, LE vs. ZG

than in children and adolescents with normal weight (15.7 and $12.0 \%$ respectively) (Fig. 7).

In the studied population there were no differences in the percentage of elevated fasting glucose between boys and girls in both cities (data not shown).
The highest percentage of physically active children and adolescents was noted both ZG and LE in 7-12 yearold (59.6 and $51.7 \%$ respectively) compared to older age groups of $13-15$-year-olds (38.3 and $48.3 \%$ respectively) and 16 -year olds ( 39.5 and $48.8 \%$ respectively). 


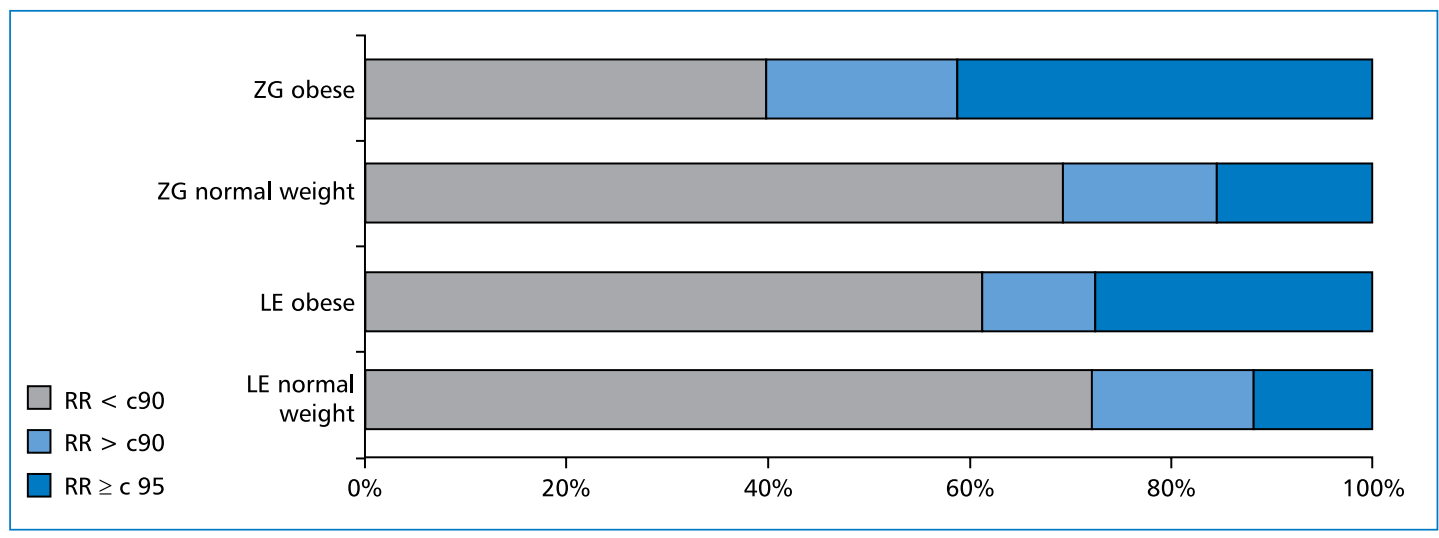

Figure 7. Comparison of blood pressure of study participants in different weight groups, LE vs. ZG

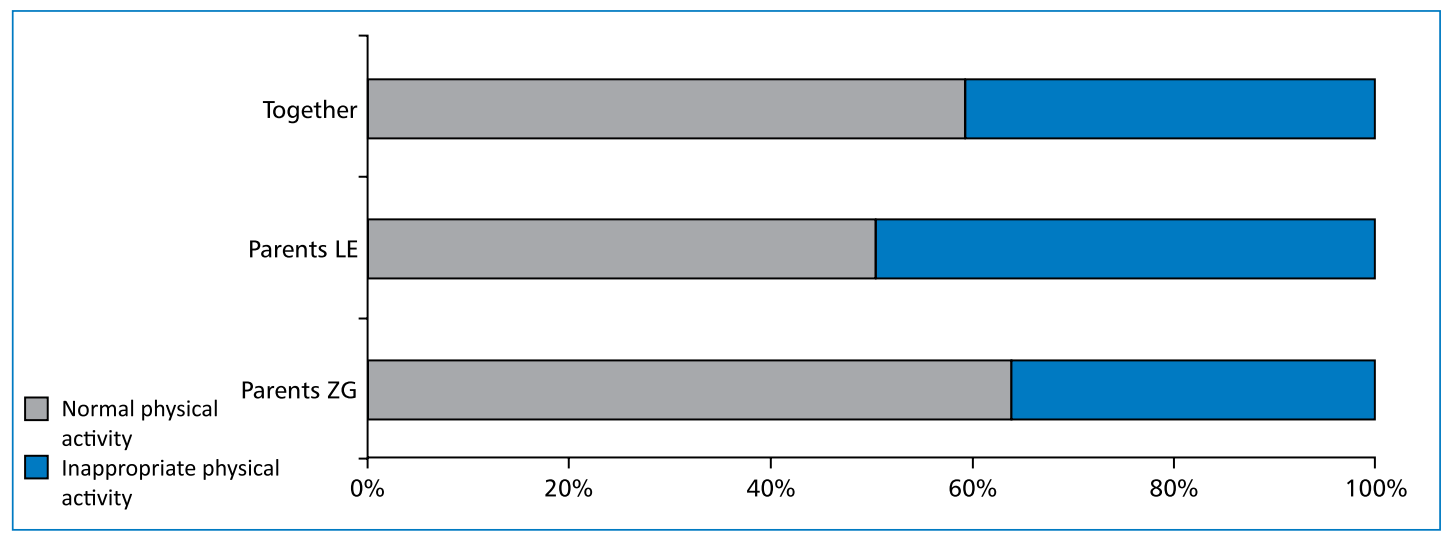

Figure 8. Comparison of parental knowledge on children's physical activity, LE vs. ZG

The difference in physical activity between these age groups was significant ( $p<0.001$ ) (data not shown).

Children and adolescents aged 7-12 years, both in ZG and LE adhered the best to the healthy eating standards (57.7 and $68.2 \%$ respectively). On the opposite adolescents aged 16 years most often did not follow the rules of healthy eating (data not shown).

Parents/legal guardians of children's both in ZG and LE regarded the physical activity of their children as normal (respectively 63.9\%, 50.7\%) ( $p>0.05$ ) (Fig. 8).

Both in ZG (88.0\%) and LE (88.0\%), most parents/ /legal guardians accepted their children's dietary habits (Fig. 9) $(p>0.05)$.

\section{Discussion}

It is estimated that approximately $10 \%$ of the world population aged < 18 years is overweight or obese [15-17]. Over the last 30 years, the incidence of obesity in children and adolescents has tripled worldwide [18-21]. In Poland, the prevalence of obesity in children and adolescents is approximately $12-14 \%$ and shows huge interregional variation [11, 22]. The situation is relatively well recognized in large cities. Less much is known about the incidence of abnormal body weight in medium size and in the rural areas like ZG and LE. We observed that obesity was more frequent in ZG compared to LE. This correlates with observations of Silesian children, indicating differences in body weight, depending on the region and place of residence $[23,24]$.

The higher incidence of obesity in boys compared to girls $(14 \%$ vs. $13.8 \%)$ was shown in the US and Greece $[1,25]$. The Polish OLAF study showed that obesity and overweight in children aged 7-18 years affects approximately $18 \%$ of boys and $14 \%$ of girls [5] with slightly lower values given by other investigators $[24,26]$. We have also confirmed this association since both in medium sized city (ZG) and rural area (LE) obesity was more frequently observed in boys.

Abdominal obesity is associated with an adverse lipid profile, insulin resistance and hyperinsulinemia and is regarded an important criterion for diagnosis of MS in 


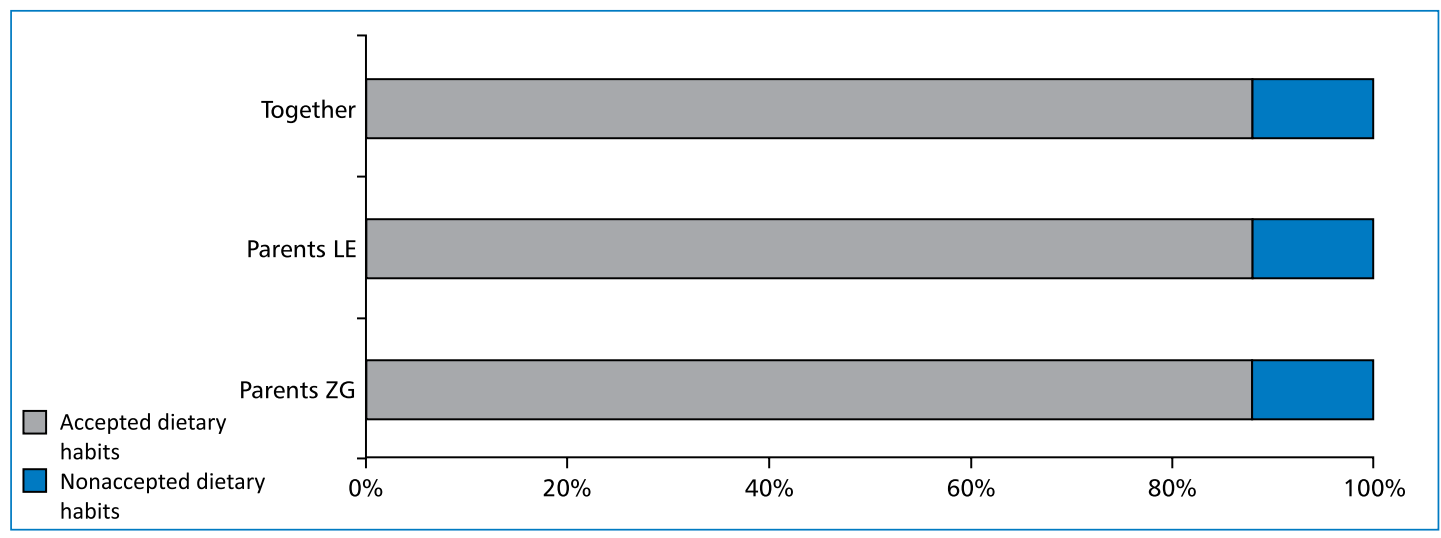

Figure 9. Comparison of parental knowledge on dietary habits of children, LE vs. ZG

children and adolescents [4, 21, 27]. A simple indicator of abdominal obesity (WC) allows indirect assessment of abdominal fat content [28]. According to NHANES III study prevalence of MS among American youth aged $12-19$ years increased from $4.2 \%$ in $1988-1994$ to $6.4 \%$ in 1999-2000 [29]. In Poland, the percentage depends on the criteria used, and varies from 15 to $30 \%[16,30]$. In our study, WC $\geq 90$ c was most frequently observed among the youngest children and among boys. In the older age groups WC is much less likely to differ from what is accepted as a norm. This observation may confirm the physiological changes in fat distribution with age. Report of the American Academy of Pediatrics (AAP) emphasizes the role of improper diet and lack of physical activity for the development of obesity [30, 31]. Poland national studies indicate that the breakfast is eaten by only $70 \%$ of children. Lunch of $30 \%$ of polish children consists of sweets and high calories drinks [32]. Sławińska et al., noted that dietary errors increase with age [33]. Our results confirm incorrect quantity and quality of meals throughout the day in both populations. As described earlier this phenomenon increases with age, especially in boys.

Numerous observations have shown that lack of physical activity and abnormally long leisure time in teenagers, is often not corrected and accepted by the parents [34, 35]. Additionally, activities carried out with a minimum of physical activity, usually in a seated position, are the preferred form of leisure activity in children and young adults $[11,35]$. The vast majority of teens practice once or twice a week and spends no more than 3 to 4 hours a week on physical exercises [34]. Our results confirm a relatively low physical activity in teenagers. A significant percentage of study participants spend more than two hours a day watching TV or using a PC and consume more low-quality high-calorie products. This was especially true for obese adolescents in the oldest age group, who additionally often not exercise during PE lessons.

It has been shown that excessive weight and obesity are more common among children living in bigger cities than in rural areas [36]. These observations only partially overlap with the observations in the populations of ZG and LE, because a higher incidence of obesity was observed in children and adolescents living in the medium size city compared to the rural area.

Studies conducted in the United States and Poland have shown that hypertension is present in approximately $50 \%$ of obese children (53\% and $40.7 \%$ respectively) and only in $9 \%$ of children with normal weight $[30,37]$. Meta-analysis has shown that obese children compared to their normal weight peers are 3-5 times more prone to hypertension [38]. Obesity is a stronger risk factor for HT in teenage boys than girls [39]. These observations are in agreements with our results, because the blood pressure $\geq c 95$ was seen in over $16 \%$ of the study population. Additionally, blood pressure exceeding > c90 (prehypertension) was seen in a significant percentage of the study population both in ZG and LE. Due to the fact that early diagnosis of high blood pressure in children and adolescents is an important prognostic factor, parents and children participating in the study were informed of the results of the survey and the need to consult with family physician.

According to many authors, diabetes and abnormal high blood pressure in children - recognized risk factors for CVD - significantly increase the risk of premature death. The coexistence of these two pathologies accelerates the development of atherosclerosis in early childhood $[38,40]$. The results of our study indicate that elevated glucose was reported most frequently in the group of 13-15 year-olds, regardless of the gender of the study participant. It was also found more common among teenagers in the middle size town compared to rural area. 
Epidemiological studies in children and adolescent most often assess excess body weight. However, malnutrition in this age group is not uncommon even in developed countries. Among the causes of malnutrition low socioeconomic status of the family, access to food, a number of environmental factors (cultural, ethnic), but also non-healthy lifestyle are mentioned [41]. Clinical observations show that early detection of malnutrition is a key element in the prevention of serious pathologies in children [42]. According to the research of the Institute of Food and Nutrition Insitute approximately $30 \%$ of Polish school children are malnourished [43]. Lower number were reported by Szponar et al. and Białkoz-Kalinowska et al. [42, $44,45]$. The results of our study confirm the high rate of malnutrition among children and adolescents in ZG and LE. This phenomenon was found in $7 \%$ of the study population. At the same time low body weight was observed more frequently in ZG, especially in boys.

The dominant role of parents in preventing weight abnormalities in children is continuously stressed. Collins et al., indicate that parents should be involved in prevention and treatment of obesity in children. Unfortunately, parents themselves do not often adhere to the principles of a healthy lifestyle [35]. Obesity in children is still not considered a factor contributing to the development of many metabolic diseases in the future. An important factor responsible for eating disorders in children is the lack of knowledge about the factors contributing to the health of children [39, 46]. These observations are supported by the findings in the population ZG and LE. Surveyed parents often do not perceive their children's eating habits as bad.

\section{Conclusions}

In the examined population of medium size city and rural area, the prevalence of obesity among children and adolescents was similar to those seen in this age group living in big cities. In this population multivariate analysis points out the key role of environmental factors and gender in the development of overweight and obesity. It is therefore important to take all preventive measures to reduce the risk of obesity complications in the future. These activities should not only be multi-directional but also possible to implement since the earliest years of life. The intervention should embrace the child, family, nursery school, kindergarten and school. These tasks, however, require an efficient system of education and medical care.

The work funded by the Medical University of Lodz; found number 503/0-077-09/503-01-006

\section{REFERENCES}

1. Roditis ML, Parlapani ES, Tzotzas T, et al. Epidemiology and predisposing factors of obesity in Greece: from the Second World War until today. J Pediatr Endocrinol Metab. 2009; 22(5): 389-405, indexed in Pubmed: 19618657.

2. Biela U, PająkA, Kaczmarczyk-Chałas K, et al. Częstość występowania nadwagi i otyłości u kobiet i mężczyzn w wieku 20-74 lat. Wyniki programu WOBASZ. Kardiol Pol. 2005; 63: 632-5.

3. International Obesity Task Force. European Union Platform Briefing Paper. Brussels, 15.03.2005. http://ec.europa.eu/health/ph_determinants/life_style/nutrition/documents/iotf_en.pdf 5.08.2011.

4. Zimmet P, Alberti KG, Kaufman F, et al. IDF Consensus Group. The metabolic syndrome in children and adolescents - an IDF consensus report. Pediatr Diabetes. 2007; 8(5): 299-306, doi: 10.1111/j.1399-5448.2007.00271.x, indexed in Pubmed: 17850473.

5. Kułaga Z, Litwin M, Zajączkowska MM, et al. Regionalne różnice parametrów antropometrycznych oraz ciśnienia tętniczego uczniów w wieku 7-18 lat. Probl Hig Epidemiol. 2009; 90: 32-41.

6. Ostrowska-Nawarycz L, Nawarycz T. Ciśnienie tętnicze oraz parametry i wskaźniki stanu odżywienia u dzieci i młodzieży łódzkiej w wieku 3-19 lat. Normy i postępowanie diagnostyczne, prewencja. Wyd. Uniwersytet Medyczny w Łodzi. Łódź 2008.

7. Franks PW, Hanson RL, Knowler WC, et al. Childhood obesity, other cardiovascular risk factors, and premature death. N Engl J Med. 2010; 362(6): 485-493, doi: 10.1056/NEJMoa0904130, indexed in Pubmed: 20147714.

8. Reilly JJ. Obesity in childhood and adolescence: evidence based clinical and public health perspectives. Postgrad Med J. 2006; 82(969): 429-437, doi: 10.1136/pgmj.2005.043836, indexed in Pubmed: 16822919.

9. Lifshitz F. Obesity in children. J Clin Res Pediatr Endocrinol. 2008; 1(2): 53-60, doi: 10.4008/jcrpe.v1i2.35, indexed in Pubmed: 21318065.

10. Grundy SM, Cleeman JI, Daniels SR, et al. Diagnosis and Management of the Metabolic Syndrome: An American Heart Association/ /National Heart, Lung, and Blood Institute Scientific Statement. Circulation. 2005; 112(17): 2735-2752, doi: 10.1161/circulationaha.105.169404, indexed in Pubmed: 16157765.

11. Ministerstwo Zdrowia Departament Polityki Zdrowotnej Program zdrowotny: Narodowy Program Zapobiegania Nadwadze i Otyłości oraz Przewlekłym Chorobom Niezakaźnym poprzez Poprawę Żywienia i Aktywności Fizycznej na lata 2007-2011. http://www.mz.gov.pl 30.07.2012.

12. Główny Urząd Statystyczny. Stan Zdrowia Ludności w Polsce w 2009 roku. Warszawa 2011. http://www.stat.gov.pl 17.07.2012.

13. The Fourth Report on the Diagnosis, Evaluation, and Treatment of High Blood Pressure in Children and Adolescents. Pediatrics. 2004; 114(2): 555-576, doi: 10.1542/peds.114.2.s2.555.

14. Obesity: preventing and managing the global epidemic. Report of a WHO consultation. World Health Organ Tech Rep Ser. 2000; 894: i-xii, 1, indexed in Pubmed: 11234459.

15. Haslam DW, James WP. Obesity. Lancet. 2005; 366(9492): 1197-1209, doi: 10.1016/S0140-6736(05)67483-1, indexed in Pubmed: 16198769.

16. Han JC, Lawlor DA, Kimm SYS. Childhood obesity. Lancet. 2010; 375(9727): 1737-1748, doi: 10.1016/S0140-6736(10)60171-7, indexed in Pubmed: 20451244.

17. Hedley $A A$, Ogden $C L$, Johnson $C L$, et al. Prevalence of overweight and obesity among US children, adolescents, and adults, 1999-2002. JAMA. 2004; 291(23): 2847-2850, doi: 10.1001/ /jama.291.23.2847, indexed in Pubmed: 15199035.

18. Sweeting HN. Measurement and definitions of obesity in childhood and adolescence: a field guide for the uninitiated. Nutr J. 2007; 6: 32, doi: 10.1186/1475-2891-6-32, indexed in Pubmed: 17963490.

19. Ebbeling CB, Pawlak DB, Ludwig DS. Childhood obesity: publichealth crisis, common sense cure. Lancet. 2002; 360(9331): 
473-482, doi: 10.1016/S0140-6736(02)09678-2, indexed in Pubmed: 12241736 .

20. Daniels SR, Arnett DK, Eckel RH, et al. Overweight in children and adolescents: pathophysiology, consequences, prevention, and treatment. Circulation. 2005; 111(15): 1999-2012, doi: 10.1161/01.CIR.0000161369.71722.10, indexed in Pubmed: 15837955.

21. Speiser PW, Rudolf MCJ, Anhalt H, et al. Obesity Consensus Working Group. Childhood obesity. J Clin Endocrinol Metab. 2005; 90(3): 1871-1887, doi: 10.1210/jc.2004-1389, indexed in Pubmed: 15598688.

22. Otto-Buczkowska E. Narastająca epidemia otyłości jako przyczyna zagrożenia zdrowia dzieci i młodzieży. Medycyna Metaboliczna. 2012; 16: 52-58.

23. Malecka-Tendera E, Klimek K, Matusik P, et al. Polish Childhood Obesity Study Group. Obesity and overweight prevalence in Polish 7- to 9-year-old children. Obes Res. 2005; 13(6): 964-968, doi: 10.1038/oby.2005.112, indexed in Pubmed: 15976137.

24. Szczepańska E, Piórkowska K, NiedworokE, et al. Konsumpcja słodyczy i napojów wysokosłodzonych $w$ aspekcie występowania otyłości na przykładzie dzieci zamieszkujących obszary miejskie i wiejskie. Endokrynologia Otyłość i Zaburzenia Przemiany Materii. 2010; 2: 78-84.

25. Ogden CL, Carroll MD, Curtin LR, et al. Prevalence of overweight and obesity in the United States, 1999-2004. JAMA. 2006; 295(13): 1549-1555, doi: 10.1001/jama.295.13.1549, indexed in Pubmed: 16595758.

26. Trzcińska D, Olszewska E, Tabor P. Zdrowotna gotowość szkolna dzieci z nadwagą i otyłością na tle grupy rówieśniczej. Pediatr Endokrynol Diabetes Metab. 2008; 14: 193-198.

27. Thompson JL. Obesity and consequent health risks: is prevention realistic and achievable? Arch Dis Child. 2008; 93(9): 722-724, doi: 10.1136/adc.2008.141523, indexed in Pubmed: 18719156.

28. Pac-Kożuchowska E, Zatorska-Karpuś $M$, Kozłowska $M$, et al. Wybrane czynniki ryzyka zespołu metabolicznego u dzieci. Pediatr Endokrinol Diabetes Metab. 2008; 14: 15.

29. Wildman RP, Muntner P, Reynolds K, et al. The obese without cardiometabolic risk factor clustering and the normal weight with cardiometabolic risk factor clustering: prevalence and correlates of 2 phenotypes among the US population (NHANES 1999-2004). Arch Intern Med. 2008; 168(15): 1617-1624, doi: 10.1001/archinte.168.15.1617, indexed in Pubmed: 18695075.

30. Litwin M. Nadciśnienie tętnicze. Medycyna Praktyczna - Pediatria. 2011; 6: 96-98.

31. Daniels SR, Greer FR. Committee on Nutrition. Lipid screening and cardiovascular health in childhood. Pediatrics. 2008; 122(1): 198-208, doi: 10.1542/peds.2008-1349, indexed in Pubmed: 18596007.
32. Zimna-Walendzik E, Kolmaga A, Tafalska E. Styl życia — aktywność fizyczna, preferencje żywieniowe dzieci kończących szkołę podstawową. Żywność Nauka Technologia Jakość. 2009; 4: 195-203.

33. Sławińska T, Kochan K, Krynicka I, et al. Zachowania zdrowotne dzieci i młodzieży w wieku 7-16 lat. Roczn PZH. 2010; 2: 165-171.

34. Ministerstwo Sportu: Strategia rozwoju sportu w Polsce do roku 2015. Warszawa, 1, 2007. http://msport.gov.pl pdf 21.12.2011.

35. American Academy of Pediatrics: Children, Adolescents, and Television. Pediatrics. 2001; 107(2): 423-426, doi: 10.1542/peds.107.2.423.

36. Sawaryn D, Kocjan E. Otyłość prosta u dzieci w wieku gimnazjalnym w świetle przeprowadzonych badań w mieście Rzeszowie i Baszni Dolnej. Nowa Pediatria. 2010; 1: 2-14.

37. Robinson RF, Batisky DL, Hayes JR, et al. Body mass index in primary and secondary pediatric hypertension. Pediatr Nephrol. 2004; 19(12): 1379-1384, doi: 10.1007/s00467-004-1588-8, indexed in Pubmed: 15503182.

38. Feld LG, Corey H. Hypertension in childhood. Pediatr Rev. 2007; 28(8): 283-298, doi: 10.1542/pir.28-8-283, indexed in Pubmed: 17670953.

39. Huang RC, Mori TA, Burrows S, et al. Sex dimorphism in the relation between early adiposity and cardiometabolic risk in adolescents. J Clin Endocrinol Metab. 2012; 97(6): E1014-E1022, doi: 10.1210/jc.2011-3007, indexed in Pubmed: 22442267.

40. Chrzanowska J, Zubkiewicz-Kucharska A, Noczyńska A. Ocena stężeń adipocytokin oraz parametrów metabolicznych u dzieci z otyłością. Pediatr Endocrinol Diabetes Metab. 2011; 17: 145-151.

41. Woynarowska B, Małkowska-Szkutnik A, Mazur J, et al. Posiłki szkolne i polityka w zakresie promocji zdrowego żywienia w szkołach w Polsce. Med Wieku Rozwoj. 2011; 15: 232-239.

42. Szponar L, Ołtarzewski M. Epidemiologia niedożywienia dzieci i młodzieży w Polsce. Pediatria Współczesna Gastroenterologia Hepatologia Żywienie Dziecka. 2004; 6: 13-17.

43. Szczepanik-Barczewska E, Borek D, Hasiec T, et al. Zespół metaboliczny u dzieci - przegląd piśmiennictwa. Problemy Medycyny Rodzinnej. 2009; 4: 41-44.

44. Białkoz-Kalinowska I, Abramowicz P, Konstantynowicz J, et al. Ocena stanu odżywienia dzieci w wieku wczesnoszkolnym z regionu Podlasia. Pediatria Pol. 2007; 2: 127-129.

45. Oblacińska A, Tabak I, Jodkowska M. Demograficzne i regionalne uwarunkowania niedoboru masy ciała u polskich nastolatków. Przegl Epidemiol. 2007; 61: 785.

46. Wojcicki JM, Heyman MB. Let's Move - childhood obesity prevention from pregnancy and infancy onward. N Engl J Med. 2010; 362(16): 1457-1459, doi: 10.1056/NEJMp1001857, indexed in Pubmed: 20393165. 